\title{
Interplay between Vitamin D, Obesity, and Other Metabolic Factors in a Multiethnic Adult Cohort
}

\author{
Khadeeja Mohammed Khalid Mansoor ${ }^{\mathrm{a}}$ Sumaiya Iqbal ${ }^{\mathrm{a}}$ Nowfala Nowshad ${ }^{\mathrm{a}}$ \\ Dima Abdelmannan ${ }^{\text {b }}$ \\ aDubai Health Authority, Medical Education Department, Rashid Hospital, Dubai, United Arab Emirates; \\ bDubai Diabetes Centre, Dubai Health Authority, Dubai, United Arab Emirates
}

\section{Keywords}

Vitamin D · Obesity · Body mass index · Dubai · Lipid profile

\begin{abstract}
Introduction: Vitamin D deficiency and obesity have been classified as pandemic issues worldwide with high prevalence of both the risk factors in the United Arab Emirates. In recent years, obesity has been associated with vitamin $D$ deficiency, but very few studies have been published about the correlation between them in the UAE population. Subjects and Methods: This is a cross-sectional study designed to find a correlation between vitamin D deficiency and obesity along with other metabolic factors. Data were collected from electronic medical records of 300 subjects ranging from 15 to 85 years of age of various ethnic origins residing in Dubai. Results: The study showed a high prevalence of obesity (44.9\%) and vitamin D deficiency (40.1) in our study population. There is no evidence of a relation between vitamin $D$ level and the obesity; $40.1 \%$ of the subjects were vitamin D deficient, out of which $46.7 \%$ were obese. However, a statistically significant relationship was found between cholesterol levels and vitamin D levels. Similarly, a significant relation was found between decreasing Vitamin D levels and increasing age but no relationship was detected with gender. Con-
\end{abstract}

karger@karger.com www.karger.com/dde

Karger $\stackrel{\text { ' }}{5}$

GOPEN ACCESS
(C) 2020 The Author(s)

Published by S. Karger AG, Basel

This article is licensed under the Creative Commons AttributionNonCommercial-NoDerivatives 4.0 International License (CC BY NC-ND) (http://www.karger.com/Services/OpenAccessLicense). Usage and distribution for commercial purposes as well as any distribution of modified material requires written permission. clusions: The present study revealed an alarming prevalence of obesity and vitamin D deficiency. Further steps need to be taken to tackle this growing problem.

(C) 2020 The Author(s)

Published by S. Karger AG, Basel

\section{Introduction}

Vitamin D deficiency and obesity are considered pandemic issues worldwide [1]. According to the World Health Organization, the rate of obesity has tripled since 1975 with $>1.9$ billion and 650 million adults being overweight and obese, respectively, and almost $50 \%$ of the population has insufficient vitamin $\mathrm{D}$ levels [2]. In the United Arab Emirates, the increasing prevalence of obesity and vitamin $\mathrm{D}$ deficiency is considered an important public issue [3].

A study conducted in UAE found $31.4 \%$ males and $36.5 \%$ females to be obese, with $44.7 \%$ males and $35.5 \%$ females found to be overweight [4]. Another study carried out across various emirates of the country found $74 \%$ of participants deficient in vitamin $\mathrm{D}[5,6]$.

Obesity is a well-known risk factor for adverse health outcomes such as diabetes and cardiovascular diseases. 
Once considered a problem only in high-income countries, overweight and obesity are now dramatically on the rise in low- and middle-income countries due to genetic factors, increased urbanization with improved living conditions, greater consumption of unhealthy food, and decreased physical activity that has caused an increase in obesity in children, adolescents, and adults, especially women [7].

Vitamin D deficiency has also been linked to various musculoskeletal problems such as bone fractures, osteomalacia, osteoporosis, and muscle weakness [3]; cardiovascular diseases such as congestive heart failure, peripheral vascular disease, and hypertension; and others such as rheumatoid arthritis, multiple sclerosis, inflammatory bowel diseases, and cancers [8]. Vitamin D is a fat-soluble vitamin largely affected by ultraviolet light exposure, dietary intake, and supplementation [3], the main source being cutaneous production via the action of UVB irradiation which converts 7-dehydrocholesterol to previtamin D3 in the epidermis of the skin. Hydroxylation in the liver results in the formation of 25-hydroxyvitamin D3 which is then stored in adipose tissue. When required by the body, the liver and kidney form the biologically active form of 1,25-dihydroxyvitamin D3. The 2 most important forms of vitamin D are vitamin D3 (cholecalciferol) and vitamin D2 (ergocalciferol). In contrast to vitamin D3, the human body cannot produce vitamin D2 which is taken up with fortified food or supplements. In human plasma, vitamin D2 and vitamin D3 are bound to proteins and transported to the liver where both hydroxylate to form 25-hydroxyvitamin $\mathrm{D}$. The primary circulating form of 25-hydroxyvitamin D is biologically inactive with levels thousandfolds greater than circulating 1,25-dihydroxyvitamin D.

In recent years, obesity has been associated with vitamin D deficiency [9-11]. Evidence from various research studies report that the concentration of vitamin $\mathrm{D}$ is inversely correlated with body weight [12]. Four suggested mechanisms commonly cited in the literature [13] give an explanation to the low vitamin D status seen in obese individuals. First, vitamin D is sequestered within the adipose tissue. Second, obese individuals receive decreased sun exposure in comparison with their lean counterparts. Third, the negative feedback mechanism was seen in obese individuals from an increased $1,25(\mathrm{OH}) \mathrm{D}$ concentration, decreasing 25(OH)D level. Lastly, low 25(OH)D concentration is simply due to volumetric dilution.

Very few studies have been published about the correlation between obesity and vitamin $\mathrm{D}$ deficiency in the UAE population. Through this cross-sectional research,
Table 1.Definitions and distribution of demographic characteristics and biochemical parameters

\begin{tabular}{lc}
\hline Variable & Subjects, $n(\%)$ \\
\hline Age & \\
$\quad 15-39$ years & $77(29.1)$ \\
$\quad 40-62$ years & $167(63)$ \\
$\quad \geq 63$ years & $21(7.9)$ \\
Gender & \\
$\quad$ Female & $164(61.4)$ \\
Vitamin D level $(\mathrm{ng} / \mathrm{mL})$ & $107(40.1)$ \\
$\quad$ Deficient & $90(33.7)$ \\
$\quad$ Insufficient & $70(26.2)$ \\
$\quad$ Sufficient & \\
BMI & $46(17.2)$ \\
$\quad \leq 24.9 \mathrm{~kg} / \mathrm{m}^{2}$ & $101(37.8)$ \\
$\quad 25-29.9 \mathrm{~kg} / \mathrm{m}^{2}$ & $120(44.9)$ \\
$\quad \geq 30.0 \mathrm{~kg} / \mathrm{m}^{2}$ & \\
Total cholesterol & $58(25.2)$ \\
$\quad>200 \mathrm{mg} / \mathrm{dL}$ & $146(63.5)$ \\
HDL cholesterol & \\
$\quad>45 \mathrm{mg} / \mathrm{dL}$ & $30(13.1)$ \\
LDL cholesterol & \\
$\quad>150 \mathrm{mg} / \mathrm{dL}$ & $28(12.2)$ \\
Triglycerides & \\
$\quad>200 \mathrm{mg} / \mathrm{dL}$ &
\end{tabular}

BMI, body mass index; HDL, high-density lipoprotein; LDL, low-density lipoprotein.

we aim to address whether the rates of obesity are higher in vitamin $\mathrm{D}$ deficient subjects, correlate vitamin $\mathrm{D}$ levels with other metabolic factors, and identify the demographic variables associated with vitamin $\mathrm{D}$ deficiency. Hence, results from this study can be useful for promoting further research in this area.

\section{Patients and Methods}

\section{Study Design}

This is a cross-sectional study to determine if the risk factor (vitamin D deficiency) is related to the disease state (obesity). Data from approximately 300 subjects with ages ranging between 15 and 85 years and of several ethnic groups (UAE, India, Pakistan, and Egypt) were collected over a period of 3 months. Of these, 267 individuals were finalized as they had complete data sets of body mass index (BMI), vitamin D, and lipid profile. Subjects excluded are those who are on vitamin D and calcium supplementation, pregnant or lactating, endocrine disorder (e.g., parathyroid disorder) and renal disorders (hemodialysis and transplantation), and those using weight loss agents in the last 6 months. 
Table 2. Relationship between serum $25(\mathrm{OH}) \mathrm{D}$ status and gender, age, and categories of BMI classes

\begin{tabular}{|c|c|c|c|c|c|}
\hline \multirow[t]{2}{*}{ Parameters } & \multirow[t]{2}{*}{ Classes } & \multicolumn{3}{|c|}{$25(\mathrm{OH}) \mathrm{D}$ status, $n(\%)$} & \multirow[t]{2}{*}{$p$ value } \\
\hline & & deficient & insufficient & sufficient & \\
\hline Subjects & & $107(40.1)$ & $90(33.7)$ & $70(26.2)$ & \\
\hline Gender & $\begin{array}{l}\text { Male } \\
\text { Female }\end{array}$ & $\begin{array}{l}40(37.4) \\
67(62.6)\end{array}$ & $\begin{array}{l}41(45.6) \\
49(54.4)\end{array}$ & $\begin{array}{l}22(31.4) \\
48(68.6)\end{array}$ & 0.181 \\
\hline Age & $\begin{aligned} & 15-39 \text { years } \\
& 40-62 \text { years } \\
\geq & 63 \text { years }\end{aligned}$ & $\begin{array}{c}41(38.3) \\
58(54.2) \\
8(7.5)\end{array}$ & $\begin{array}{c}28(31.8) \\
56(63.6) \\
4(4.5)\end{array}$ & $\begin{array}{c}8(11.4 \%) \\
53(75.7) \\
9(12.9)\end{array}$ & 0.002 \\
\hline BMI & $\begin{aligned} \leq & 24.9 \mathrm{~kg} / \mathrm{m}^{2} \\
& 25.0-29.9 \mathrm{~kg} / \mathrm{m}^{2} \\
\geq & 30.0 \mathrm{~kg} / \mathrm{m}^{2}\end{aligned}$ & $\begin{array}{l}22(20.6) \\
35(32.7) \\
50(46.7)\end{array}$ & $\begin{array}{l}12(13.3) \\
38(42.2) \\
40(44.4)\end{array}$ & $\begin{array}{l}12(17.1) \\
28(40.0) \\
30(42.9)\end{array}$ & 0.57 \\
\hline
\end{tabular}

BMI, body mass index. $\chi^{2}$ test.

Outcome Measures

The demographics and clinical data were retrieved from electronic medical records for age, ethnicity, gender, serum 25(OH)D, body mass index, and lipid profile (total cholesterol, high-density lipoprotein $[\mathrm{HDL}]$, low-density lipoprotein [LDL], and triglycerides [TAG]). BMI $<18.5 \mathrm{~kg} / \mathrm{m}^{2}$ is considered underweight, $18.5-$ $24.9 \mathrm{~kg} / \mathrm{m}^{2}$ as normal, $25-29.9 \mathrm{~kg} / \mathrm{m}^{2}$ as overweight, and $>30 \mathrm{~kg} /$ $\mathrm{m}^{2}$ as obese [13]. Obesity was graded as grade I (BMI $30-34.9 \mathrm{~kg} /$ $\mathrm{m}^{2}$ ), grade II (BMI $\left.35-39.9 \mathrm{~kg} / \mathrm{m}^{2}\right)$, and grade III $\left(\mathrm{BMI}>40 \mathrm{~kg} / \mathrm{m}^{2}\right)$ [14]. The serum total $25(\mathrm{OH}) \mathrm{D}>30 \mathrm{ng} / \mathrm{mL}$ is deemed sufficient, 20-30 ng/mL was considered insufficient, and levels $<20 \mathrm{ng} / \mathrm{mL}$ was deficient [15]. Based on Dubai Health Authority, the reference range for lipid profiles is as follows: total cholesterol, 50-200 mg/ $\mathrm{dL}$; triglycerides, <200 mg/dL; LDL, 0-150 mg/dL; and HDL, > 45 $\mathrm{mg} / \mathrm{dL}$.

\section{Statistical Analysis}

Statistical analyses were performed using SPSS version 24 . The results are expressed categorically in counts and percentages, and the differences between groups were tested using the $\chi^{2}$ test. Because of the negligible number of subjects under the BMI category of underweight, it was combined with normal BMI classification in order to facilitate the process of statistical analysis. The $p$ value of $<0.05$ is considered statistically significant.

\section{Results}

\section{Characteristics of the Study Population}

A total of 267 patients met the inclusion criteria (Table 1). Sixty-three percent of the study population is within the age group of 40-62 years with females being the majority $(164,[61.4 \%])$. Overall, $44.9 \%$ of the subjects in our study are found to be obese and $40.1 \%$ of the study population has vitamin $\mathrm{D}$ deficiency.
Relationships between Vitamin D, Gender, Age, and Obesity

In Table 2, there is no significant relation found between vitamin $\mathrm{D}$ levels and gender. In vitamin $\mathrm{D}$ deficient subjects, $62.6 \%$ of them are females, $54.4 \%$ of vitamin D insufficient subjects are females, and $68.6 \%$ of sufficient vitamin $\mathrm{D}$ subjects are females. There is a positive relationship between vitamin $\mathrm{D}$ levels and increasing age with a significant $p$ value of 0.002 . Furthermore, a statistical insignificant relationship with a $p$ value of 0.57 is found between vitamin $\mathrm{D}$ deficiency and obesity with $46.7 \%$ of vitamin $\mathrm{D}$ deficient subjects being obese, $44.4 \%$ are obese among vitamin D insufficient subjects, and $42.9 \%$ are obese among vitamin $\mathrm{D}$ sufficient subjects.

\section{Relationship of Vitamin D Deficiency and Lipid Profiles}

In Table 3, a statistical significant relation is found between vitamin D levels and cholesterol with $34 \%$ of the vitamin $\mathrm{D}$ deficient group are with abnormal cholesterol and $19.8 \%$ of insufficient and $19 \%$ of sufficient vitamin D level groups had abnormal cholesterol levels giving a $p$ value of 0.038 . On the other hand, there is no significant relation between vitamin D level and HDL levels $(p$ value $=0.52$ ). We also found a significant relation between vitamin $\mathrm{D}$ and LDL levels. The percentage of abnormal LDL in the vitamin D deficient group is $20.4 \%$, whereas the same percentage is $8.2 \%$ in the insufficient group and $7.9 \%$ in the sufficient group giving a significant $p$ value of 0.02 . Lastly, there is no relation found between vitamin $\mathrm{D}$ and TAGs with $p$ value $=0.97$. 
Table 3. The relationship between serum 25(OH) vitamin D status and serum total cholesterol, HDL cholesterol, calculated LDL cholesterol, and triglycerides levels

\begin{tabular}{|c|c|c|c|c|c|}
\hline \multirow[t]{2}{*}{ Parameters } & \multirow[t]{2}{*}{ Classes/cutoff points } & \multicolumn{3}{|c|}{$25(\mathrm{OH}) \mathrm{D}$ status, $n(\%)$} & \multirow[t]{2}{*}{$p$ value } \\
\hline & & deficient & insufficient & sufficient & \\
\hline Subjects, $n$ & & 94 & 73 & 63 & \\
\hline Total cholesterol & $\begin{array}{l}\leq 200 \mathrm{mg} / \mathrm{dL}(n=152) \\
>200 \mathrm{mg} / \mathrm{dL}(n=58)\end{array}$ & $\begin{array}{l}62(66) \\
32(34)\end{array}$ & $\begin{array}{l}59(80.8) \\
14(19.8)\end{array}$ & $\begin{array}{l}51(81) \\
12(19)\end{array}$ & 0.038 \\
\hline HDL cholesterol & $\begin{array}{l}\leq 45 \mathrm{mg} / \mathrm{dL}(n=84) \\
>45 \mathrm{mg} / \mathrm{dL}(n=146)\end{array}$ & $\begin{array}{l}34(36.2) \\
60(63.8)\end{array}$ & $\begin{array}{l}30(41.1) \\
43(58.9)\end{array}$ & $\begin{array}{l}20(31.7) \\
43(68.3)\end{array}$ & 0.526 \\
\hline LDL cholesterol & $\begin{array}{l}\leq 150 \mathrm{mg} / \mathrm{dL}(n=199) \\
>150 \mathrm{mg} / \mathrm{dL}(n=30)\end{array}$ & $\begin{array}{l}74(79.6) \\
19(20.4)\end{array}$ & $\begin{array}{l}67(91.8) \\
6(8.2)\end{array}$ & $\begin{array}{c}58(92.1) \\
5(7.9)\end{array}$ & 0.025 \\
\hline Triglycerides & $\begin{array}{l}\leq 200 \mathrm{mg} / \mathrm{dL}(n=202) \\
>200 \mathrm{mg} / \mathrm{dL}(n=28)\end{array}$ & $\begin{array}{l}82(87.2) \\
12(12.8)\end{array}$ & $\begin{array}{r}64(87.7) \\
9(12.3)\end{array}$ & $\begin{array}{r}56(88.9) \\
7(11.1)\end{array}$ & 0.972 \\
\hline
\end{tabular}

HDL, high-density lipoprotein; LDL, low-density lipoprotein. $\chi^{2}$ test.

\section{Discussion}

Obesity is multifactorial. It is a subject of controversy whether the vitamin D deficiency is a consequence of or a factor predisposing to obesity [16]. Based on our study, around $44.9 \%$ of population in Dubai is obese and 37.8\% is overweight showing the rising prevalence of obesity in the United Arab Emirates. This can be attributed to the steady rise in sedentary lifestyle and socioeconomic status. Furthermore, vitamin D deficiency is prevalent in $40 \%$ of the population, insufficiency in $33.7 \%$, and sufficiency in $26.2 \%$, which can be due to limited sun exposure attributed to intense heat, infrastructure, and cultural dressing [6].

Our study concluded that there is no significant relation between vitamin $\mathrm{D}$ and obesity. In vitamin $\mathrm{D}$ deficient population, $46.7 \%$ are obese, $32.7 \%$ are overweight, and $20.6 \%$ are with normal BMI, whereas in vitamin D sufficient population, $42.9 \%$ are obese and $17.1 \%$ are with normal BMI. A similar study carried out by Sneve et al. [17] found weight reduction in overweight and obese subjects is unlikely to occur with cholecalciferol supplementation.

A study of Canto-Costa et al. [18] including subjects older than 65 years did not find any correlation between serum levels of 25(OH)D and body fat percentage, weight, or BMI. Forsythe et al. [19] observed significant negative associations between baseline $25(\mathrm{OH}) \mathrm{D}$ and all anthropometric measures of body size and adiposity. In contrast, Gonzalez et al. [9] reported that the lower levels of 25(OH)D were as- sociated with higher BMI, WC, and WHR. In addition, Botella-Carretero et al. [10] showed that vitamin D deficiency was more prevalent in morbidly obese patients presenting with the metabolic syndrome. Similar data were obtained from a cross-sectional study of Chinese adults with 1,277 subjects aged $20-82$ years, suggesting that adiposity phenotypes were strongly linked to serum 25-hydroxyvitamin D levels [14]. Spearman's and Pearson's correlation showed no linear relationship between vitamin D and BMI ( $0.05=r$ correlation coefficient $)$.

In our study, there is a significant relation between age and vitamin D levels. Similar relationship was found in the study by Masoompour et al. [20] stating that in healthy men, the serum level of 25-hydroxyvitamin D did not decline with age. This can be attributed to the age-related increase in parathyroid hormone which is inversely related to vitamin $\mathrm{D}$, vitamin $\mathrm{D}$ rich diet, and proper sunlight exposure. In contrast to this, the study by Nasri et al. [21] including 259 subjects aged between 18 and 65 years states significant correlation of age and vitamin $\mathrm{D}$ but with a high prevalence of $25(\mathrm{OH}) \mathrm{D}$ deficiency in the elderly.

Our study inferred that $25(\mathrm{OH}) \mathrm{D}$ was not related to gender which explains that both males and females are equally likely to have variations in their $25(\mathrm{OH}) \mathrm{D}$ levels. Contrary to this, Sanghera et al. [22] reported that vitamin D levels remained significantly reduced in men when compared to women.

The present study showed a significant statistical difference in the cholesterol levels and the $25(\mathrm{OH}) \mathrm{D}$ levels. 
As expected, the lower the $25(\mathrm{OH}) \mathrm{D}$, the higher the values of total cholesterol. In the cross-sectional analysis carried out across the USA, the "optimal" group relative to the "deficient" $25(\mathrm{OH}) \mathrm{D}$ group displayed lower total cholesterol, lower LDL cholesterol, higher HDL cholesterol, and lower triglycerides. The statistically significant crosssectional association between $25(\mathrm{OH}) \mathrm{D}$ levels and components of the lipid panel suggests a possible causal relationship [23]. On the contrary, a study conducted in 1,259 postmenopausal women concluded that the change in lipids was relatively small and there was no significant difference in the mean change of any lipid variable between the active and placebo groups [24].

The specific strengths and weaknesses are worthy of mention. First, perhaps the most important strength of this study is the large sample size of 267 subjects to represent the more accurate population. Second, the random sampling method which minimizes the bias in patient selection by blindly selecting and then excluding them based on exclusion criteria. And finally, to measure $25(\mathrm{OH}) \mathrm{D}$, we used the chemiluminescent immunoassay, which is more accurate than high-performance liquid chromatography (HPLC) and enzyme-linked fluorescent immunoassay [25]. On the other hand, the insignificant correlation between vitamin D deficiency and BMI has largely been influenced by the high prevalence of overweight and obesity (82.8\%). In addition to this, the sample being selected from patients of Dubai Health Authority clinics alone and $60 \%$ of the subjects being UAE nationals may not make the sample fully representative of the UAE population as a whole, where expatriates form the majority of the population. Lastly, our study is a crosssectional study that does not provide definite information about cause and effect relationships.

\section{Conclusions}

it is important that this relationship needs to be assessed further. Moreover, a clinical trial should be conducted to look at the effect of supplementation of vitamin D on body weight.

\section{Acknowledgements}

We are immensely grateful to Dr. M.Z. for his contributions in the statistical analysis of our research and to Dr. A.K. for helping us with the data collection. Finally, we would also like to express gratitude to Dr. N.R. for her support during the initiation of our research project.

\section{Statement of Ethics}

The study was approved by the University Scientific Research Ethics Committee and Dubai Scientific Research Ethics Committee at Dubai Health Authority.

\section{Conflict of Interest Statement}

The authors have no conflicts of interest to disclose.

\section{Funding Sources}

The authors did not receive any funding.

\section{Author Contributions}

All named authors contributed to the conception, conduct, and data analysis of the study and were involved in drafting, further development, and revision of the manuscript and approval of its final version.

The present study showed no significant association between vitamin D level and BMI. In this study, 40.1\% were found to be vitamin D deficient, out of which $46.7 \%$ were obese. The study was designed to understand the relation between vitamin $\mathrm{D}$ deficiency and obesity. Our aim is to further evaluate the impact of vitamin D supplementation among obese individuals, which may be an inexpensive and practical avenue of reducing the burden of obesity in United Arab Emirates, given the difficulty in management of overweight or obese status in certain individuals. This is a cross-sectional study, and no significant relationship was found between $25(\mathrm{OH}) \mathrm{D}$ and $\mathrm{BMI}$;

References
Dubai Diabetes Endocrinol J 2020;26:152-157 DOI: $10.1159 / 000511687$
1 Holick MF, Chen TC. Vitamin D deficiency: a worldwide problem with health consequences. Am J Clin Nutr. 2008;87(4):1080S$6 \mathrm{~S}$.

2 Holick MF. Vitamin D deficiency. N Engl J Med. 2007;357(3):266-81.

3 Sadiya A, Ahmed SM, Skaria S, Abusnana S. Vitamin D status and its relationship with metabolic markers in persons with obesity and type 2 diabetes in the UAE: a cross-sectional study. J Diabetes Res. 2014;2014: 869307.

4 Sulaiman N, Elbadawi S, Hussein A, Abusnana S, Madani A, Mairghani M, et al. Prevalence of overweight and obesity in United Arab Emirates expatriates: the UAE National Diabetes and Lifestyle Study. Diabetol Metab Syndr. 2017;9:88.
Mohammed Khalid Mansoor/Iqbal/ Nowshad/Abdelmannan 
5 Muhairi S, Mehairi AE, Khouri AA, Naqbi MM, Maskari FA, Al Kaabi J, et al. Vitamin D deficiency among healthy adolescents in $\mathrm{Al}$ Ain, United Arab Emirates. BMC Public Health. 2013;13(1):33.

6 Bani-Issa W, Eldeirawi K, Harfil S, Fakhry R Vitamin $\mathrm{D}$ deficiency and its determinants in adults: a sample from community-based settings in the United Arab Emirates. Int J Endocrinol. 2017;2017. 3906306.

7 Khalil AB, Beshyah SA, Abdella N, Afandi B, Al-Arouj MM, Al-Awadi F, et al. Diabesity in the Arabian Gulf: challenges and opportunities. Oman Med J. 2018 Jul;33(4):273-82.

8 Zittermann A. Vitamin D in preventive medicine: are we ignoring the evidence? $\mathrm{Br} J$ Nutr. 2003;89(5):552-72.

9 Gonzalez L, Ramos-Trautmann G, DíazLuquis GM, Perez CM, Palacios C. Vitamin D status is inversely associated with obesity in a clinic-based sample in Puerto Rico. Nut Res. 2015;35(4):287-93.

10 Botella-Carretero JI, Alvarez-Blasco F, Villafruela JJ, Balsa JA, Vázquez C, EscobarMorreale HF. Vitamin D deficiency is associated with the metabolic syndrome in morbid obesity. Clin Nutr. 2007;26:573-80.

11 Zhang Y, Zhang X, Wang F, Zhang W, Wang $\mathrm{C}, \mathrm{Yu} \mathrm{C}$, et al. The relationship between obesity indices and serum vitamin $\mathrm{D}$ levels in Chinese adults from urban settings. Asia Pac J Clin Nutr. 2016;25(2):333-9.
12 Luong KV, Nguyen LTH. The serum concen tration of 25-hydroxyvitamin D3(25OHD3) is inversely correlated with body weight. Vitamin D and obesity. Med Chem. 2012;2:011-9.

13 Center for disease control and prevention. About Adult BMI. Available from: About Adult BMI | Healthy Weight. Last accessed 2020 Feb 4

14 Clinical guidelines on the identification, evaluation, and treatment of overweight and obesity in adults: the evidence report. National Institutes of Health. Obes Res. 1998 Sep; 6(Suppl 2):51S-209S.

15 Hughes BD. Vitamin D deficiency in adults: definition, clinical manifestations, and treatment. In: Drezner MK, Rosen CJ, editors. UpToDate. Waltham, MA: UpToDate Inc; 2018.

16 Yao Y, Zhu L, He L, Duan Y, Liang W, Nie Z, et al. A meta-analysis of the relationship between vitamin D deficiency and obesity. Int J Clin Exp Med. 2015;8(9):14977-84.

17 Sneve M, Figenschau Y, Jorde R. Supplementation with cholecalciferol does not result in weight reduction in overweight and obese subjects. Eur J Endocrinol. 2008 Dec;159(6): 675-84.

18 Canto-Costa MHS, Kunii I, Hauache OM. Body fat and cholecalciferol supplementation in elderly homebound individuals. Braz J Med Biol Res. 2006;39:91-8.
19 Forsythe LK, Livingstone MB, Barnes MS, Horigan G, McSorley EM, Bonham MP, et al. Effect of adiposity on vitamin $D$ status and the 25-hydroxycholecalciferol response to supplementation in healthy young and older Irish adults. Br J Nutr. 2012;107(1):126-34.

20 Masoompour S-M, Abdossamad S, Bagher L, Omrani GH. Effects of age and renal function on vitamin D status in men. Arch Iran Med. 2008;11(4):377-81.

21 Nasri H, Ardalan MR. Association of serum vitamin $\mathrm{D}$ level with age in individuals with normal renal function. J Nephropharmacol. 2012;1(1):7-9.

22 Sanghera DK, Sapkota BR, Aston CE, Blackett PR. Vitamin D status, gender differences, and cardiometabolic health disparities. Ann Nutr Metab. 2017;70(2):79-87.

23 Ponda MP, Huang X, Odeh MA, Breslow JL Kaufman HW. Vitamin D may not improve lipid levels: a serial clinical laboratory data study. Circulation. 2012;126(3):270-7.

24 Rajpathak SN, Xue X, Wassertheil-Smoller S, Van Horn L, Robinson JG, Liu S, et al. Effect of $5 \mathrm{y}$ of calcium plus vitamin $\mathrm{D}$ supplementation on change in circulating lipids: results from the Women's Health Initiative. Am J Clin Nutr. 2010;91(4):894-9.

25 Pal M, Datta S, Pradhan AK, Biswas L, Ghosh J, Mondal P, et al. Comparison between different methods of estimation of vitamin D. Adv Biol Chem. 2013;3:501-4. 